\title{
Efficacy of long-term treatment with tenofovir in Chinese nucleos(t)ide-naïve chronic hepatitis B patients regardless of baseline viral load
}

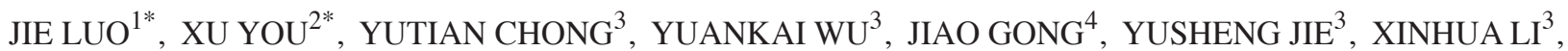 \\ SUJUAN XI ${ }^{3}$, ZHIWEI ZHANG ${ }^{3}$, YUFENG ZHANG ${ }^{3}$, DONGYING XIE ${ }^{3}$, ZHANYI LI $^{3}$ and XIANGYONG $\mathrm{LI}^{3}$ \\ ${ }^{1}$ Department of Hepatology, The Third Affiliated Hospital of Shenzhen University, \\ Shenzhen Luohu People's Hospital, Shenzhen, Guangdong 518000; ${ }^{2}$ Department of Clinical Laboratory, \\ The Third Affiliated Hospital of Southern Medical University; Departments of ${ }^{3}$ Infectious Diseases and ${ }^{4}$ Clinical Laboratory, \\ The Third Affiliated Hospital of Sun Yat-sen University, Guangzhou, Guangdong 510630, P.R. China
}

Received September 20, 2018; Accepted March 26, 2019

DOI: $10.3892 / \mathrm{etm} .2019 .7547$

\begin{abstract}
The aim of the present study was to analyze the efficacy and safety of tenofovir (TDF) treatment for up to 5 years in nucleos(t)ide-naïve chronic hepatitis B (CHB) patients, particularly those with a high viral load, a in real-life scenario. A total of 144 nucleos(t)ide-naïve CHB patients who received TDF monotherapy for at least 3 months were retrospectively analyzed. The primary endpoint measure was the achievement of virological response (VR; undetectable serum HBV DNA, <100 IU/ml). The secondary endpoints were alanine aminotransferase (ALT) normalization (ALT $<$ upper limit of normal), hepatitis B e antigen ( $\mathrm{HBeAg}$ ) seroconversion and safety. The median follow-up period was 120 weeks (range, 12-264 weeks). In total, 144, 130, 114, 78, 67, 40 and 13 patients were followed up for at least 12, 24, 48, 96, 144, 192 and 240 weeks, respectively. An incremental trend was observed in the rate of VR: 73.1, 91.3, 98.1, 100, 100 and $100 \%$ of the patients exhibited VR at 24, 48, 96, 144, 192 and 240 weeks, respectively. Furthermore, 29 patients with hepatitis B virus (HBV) DNA $\geq 8 \log _{10} \mathrm{IU} / \mathrm{ml}$ at baseline achieved VR during the follow-up period. The proportions of patients achieving normal ALT levels were 72.1, 78.6, 91.2, 95,
\end{abstract}

Correspondence to: Dr Zhanyi Li or Dr Xiangyong Li, Department of Infectious Diseases, The Third Affiliated Hospital of Sun Yat-sen University, 600 Tienhe Road, Guangzhou, Guangdong 510630, P.R. China

E-mail: 1zyaly@126.com

E-mail: 1xy2005123@126.com

*Contributed equally

Abbreviations: CHB, chronic hepatitis B; PVR, partial virological response; TDF, tenofovir disoproxil fumarate; ETV, entecavir; NAs, nucleos $(\mathrm{t})$ ide analogues

Key words: hepatitis B, chronic, tenefovir, nucleos(t)ide analogues
96 and 100\%, at 24, 48, 96, 144, 192 and 240 weeks, respectively. The rate of $\mathrm{HBeAg}$ loss reached $35.6 \%$ at week 240. Among the 130 patients, HBV DNA was detectable [partial VR (PVR)] in 35 patients at 24 weeks of follow-up, and 30 of those 35 patients $(85.7 \%)$ required $>24$ weeks of further TDF therapy to achieve VR. No serious adverse events were reported. In conclusion, long-term TDF treatment of nucleos $(\mathrm{t})$ ide-naïve chronic hepatitis B patients, regardless of high viral load at baseline, was effective and safe in a real-life scenario. Adjustment of TDF monotherapy may be unnecessary in nucleos(t)ide-naïve patients with PVR at 24 weeks.

\section{Introduction}

Chronic hepatitis B (CHB) is a major health problem worldwide. In China, although the prevalence of hepatitis B virus (HBV) infection in the general population was reduced to $7.2 \%$ by 2006 , it was estimated that there were $\sim 93$ million people who were chronic $\mathrm{HBV}$ surface antigen ( $\mathrm{HBsAg}$ ) carriers, of which $\sim 20$ million were patients with chronic hepatitis B (1,2). Furthermore, in 2014, a seroepidemiological survey of HBV infection among people aged 1-29 in China revealed that the detection rates of HBsAg in people aged 1-4, 5-14 and $15-29$ years were $0.32 \%, 0.94 \%$ and $4.38 \%$ respectively (2). Most patients with $\mathrm{CHB}$ require long-term therapy. The primary goal of CHB treatment is to reduce the risk of chronic liver disease and the associated complications, and improve the quality of life and survival (2).

Anti-viral therapy, which aims to reduce the HBV DNA levels as much as possible, is key in the management of $\mathrm{CHB}$. In this regard, nucleos(t)ide analogues (NAs) are commonly used to treat $\mathrm{CHB}$ patients. Tenofovir disoproxil fumarate (TDF) and entecavir (ETV) are the most potent HBV inhibitors and have a high genetic barrier to resistance $(3,4)$. According to current guidelines, they are the recommended first-line therapeutic agents for CHB (5-7). Compared to adefovir, TDF displayed superior virological and biochemical outcomes in NA-naïve patients in a randomized controlled trial (3). TDF is able to sustain its suppressive effects on HBV 
replication without the occurrence of drug-resistant mutants after up to 8 years of continuous therapy (8). Furthermore, TDF has been reported to be efficacious and safe for $\mathrm{CHB}$ patients with multi-drug resistance (9). Another study reported that TDF is effective for achieving complete viral suppression in $\mathrm{HBeAg}$-positive, NA-naïve CHB patients with HBV DNA levels of $>6 \log _{10} \mathrm{IU} / \mathrm{ml}(10,11)$.

However, in real life, an increasing number of patients are experiencing treatment failure with different NA treatment regimens due to poor compliance or/and financial barriers. Lovett et al (12) observed the long-term treatment outcomes of tenofovir therapy in treatment-naïve and -experienced CHB patients in a real-world Australian population. They observed that the rates of complete virological suppression (defined as plasma HBV DNA levels <20 IU/ml) were 70, 87 and $100 \%$ at 12, 24 and 36 months, respectively. However, they did not perform any hierarchical analysis according to baseline HBV DNA levels. Furthermore, currently available data on virological response (VR) to long-term continuous TDF therapy in patients with a high viral load and partial VR (PVR) in the clinical setting are limited. Therefore, the present study was performed to provide objective real-life data for the clinical use of TDF.

The aims of the present retrospective study were to i) evaluate the long-term efficacy of TDF treatment in NA-naïve CHB patients with a high viral load in real life and ii) assess the efficacy of continuous TDF therapy in patients who failed to achieve VR at 24 weeks.

\section{Patients and methods}

Study population. The present retrospective study was performed using the data of consecutive patients encountered at the Department of Infectious Diseases of The Third Affiliated Hospital of Sun Yat-sen University (Guangzhou, China) between February 2012 and July 2017. All CHB patients were diagnosed on the basis of the Guidelines for the Prevention and Treatment for Chronic Hepatitis B (2015) (9) and were treated with TDF $300 \mathrm{mg} /$ day monotherapy. All of the patients were followed up once at least every 3 months to collect their serum samples. The patients were carefully examined at each follow-up visit and requested to report any adverse events. The study protocol conformed to the ethical guidelines of the Declaration of Helsinki and was approved by the Ethics Committee of the Third Affiliated Hospital of Sun Yat-sen University (Guangzhou, China). Informed consent was obtained from each patient involved in the follow-up study.

The inclusion criteria were as follows: Age, 18-65 years; presence of detectable hepatitis B surface antigen (HBsAg) levels for 6 months; HBV DNA levels >2,000 IU/ml; alanine aminotransferase (ALT) levels $>2$ upper limit of normal; duration of TDF monotherapy, at least 12 weeks. Patients were excluded if they had HIV or other hepatitis virus infections, or evidence of alcoholic hepatitis, autoimmune hepatitis or drug-induced liver disease. Pregnant and breast-feeding women were also excluded.

Among the 166 patients treated with TDF at $300 \mathrm{mg} /$ day, 22 were excluded for the following reasons: Duration of TDF monotherapy for $<12$ months $(n=14)$, incomplete data at baseline $(n=3)$ and prevention of mother-to-child transmission $(n=5)$.
A total of 144 patients were eligible for this analysis. A flowchart depicting the patient enrollment process is provided in Fig. 1.

Laboratory measurements. Routine hematologic analysis, serologic analysis and assessments of hepatobiliary enzymes, HBV DNA, hepatic synthetic function, creatine kinase, blood urea nitrogen, creatinine and blood lactate were performed at baseline and every 3-6 months thereafter. A 2-ml blood sample was collected at each follow-up examination for future assessment. The diagnosis of cirrhosis was based on the results of histological or ultrasound examinations.

Definitions of response. VR was defined as undetectable serum HBV DNA levels $(<100 \mathrm{IU} / \mathrm{ml})$. PVR was defined as a decrease in HBV DNA level by $>2.0 \log _{10} \mathrm{IU} / \mathrm{ml}$, but detectable HBV DNA in a real-time PCR assay ( $\geq 100 \mathrm{IU} / \mathrm{ml})$ at 24 weeks of TDF treatment (11). Virological breakthrough was defined as a $>1 \log _{10} I U / m l$ increase in serum HBV DNA levels from the nadir in two consecutive measurements. Virological relapse was defined as serum HBV DNA levels of $>2,000 \mathrm{IU} / \mathrm{ml}$ in two tests with a 1-month interval after withdrawing the anti-viral drug in patients who experienced VR. An ALT level of 5-40 U/1 was considered normal.

Clinical endpoints. The primary endpoint measures were the proportions of patients achieving VR at 12, 24 and 48 weeks (year 1), 96 weeks (year 2), 144 weeks (year 3), 192 weeks (year 4) and 240 weeks (year 5). The secondary endpoints were $\mathrm{HBeAg}$ loss and seroconversion, and ALT normalization.

Assay methods. Liver function assessments and other biochemical assays were performed using automated techniques. Serum HBV DNA levels were measured using a real-time quantitative PCR assay (DAAN Gene Co., Ltd) with a lower detection limit of $100 \mathrm{IU} / \mathrm{ml}$. The HBsAg (cat. no. 11820532122), HBsAb (cat. no. 11820524122), HBeAg (cat. no. 11820583122) and $\mathrm{HBeAb}$ (cat. no. 11820613122) were measured using commercially available chemiluminescence assay kits purchased from Roche Diagnostic Systems.

Statistical analysis. Data were analyzed using the SPSS software package version 19.0 (IBM Corp.). Quantitative data were expressed as the mean \pm standard deviation. Categorical data were presented as counts and percentages. HBV DNA levels were presented as log-transformed values. Student's t-test was used for quantitative data. Pearson's chi-square and Fisher's exact tests were used for categorical variables. The associations between sex, age, presence of cirrhosis, interferon experience, baseline HBV DNA, baseline $\mathrm{HBeAg}$ status, baseline ALT level and end of follow-up of virological suppression and PVR to TDF monotherapy were tested using Cox proportional hazards regression analysis. The cumulative rates of complete viral suppression were analyzed using the Kaplan-Meier method. A two-tailed $\mathrm{P}<0.05$ was considered to indicate a statistically significant difference.

\section{Results}

Baseline characteristics of patients. In total, 144 patients were included in the present study, of whom 106 were 


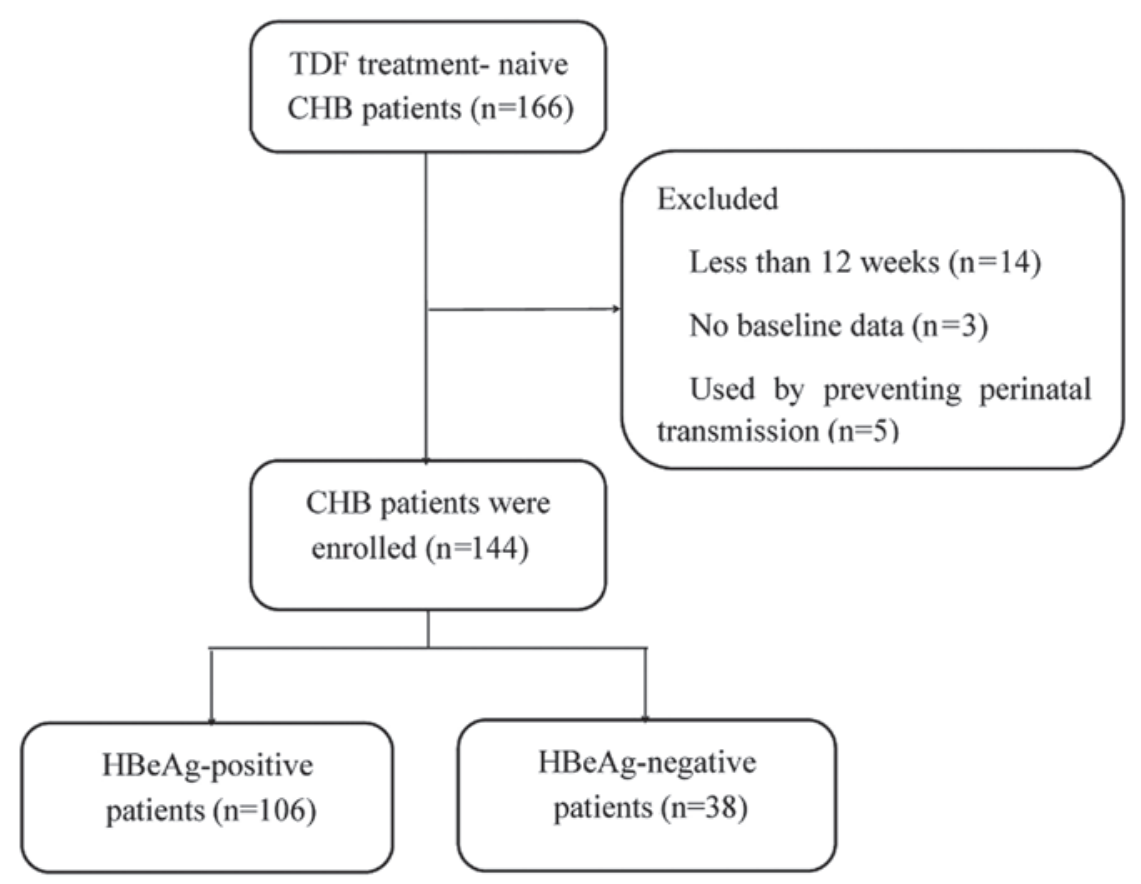

Figure 1. Flow chart of the patient enrolment for the present study. TDF, tenofovir disoproxil fumarate; CHB, chronic hepatitis B; HBeAg, hepatitis B e antigen.

HBeAg-positive and 38 were HBeAg-negative. Overall, $55.6 \%$ of the patients $(n=80)$ were male, and 25 patients $(17.4 \%)$ had cirrhosis. Five patients had undergone interferon therapy: 2 had been treated with pegylated interferon and the other 3 had received conventional interferon. One patient received treatment $<3$ months due to poor compliance, and 3 patients finally exhibited virological relapse after cessation of interferon therapy. One patient did not continue interferon therapy due to side effects and switched to TDF. The 144 patients enrolled had good compliance and took medication on time, Although 19 patients were not followed up every three months, these patients were followed up at intervals of 4 or 6 months. At each follow-up time-point, the clinicians communicated with the patients by telephone, and patients were urged to visit a doctor and receive timely education to improve treatment adherence. The mean HBV DNA level in the cohort was $6.7 \log _{10} \mathrm{IU} / \mathrm{ml}$. The mean patient age was 34 years and the median follow-up period for the whole study population was 120 weeks (range, 12-264) weeks. The baseline characteristics of the study population are presented in Table I.

$V R$. To analyze the suppression of HBV DNA, a Kaplan-Meier plot was used to visualize the cumulative probability of achieving complete viral suppression at each follow-up time-point (Fig. 2). The cumulative probability of achieving VR at 24, 48, 96, 144, 192 and 240 weeks was 71, 91.3, 98.1, 100,100 and $100 \%$, respectively. A transient elevation of the viral load was observed in 6 patients, which had an elevation of HBV DNA levels by $<1 \log _{10} \mathrm{IU} / \mathrm{ml}$. However, in the subsequent second test, the HBV DNA level dropped below the detection limit. Among these patients, HBV DNA levels in one case rose from below the limit of detection at 36 weeks to $205 \mathrm{U} / 1$ at 48 weeks, HBV DNA levels in four cases increased respectively from below the limit of detection at 60 weeks to
591, 656, 787 and $574 \mathrm{IU} / \mathrm{ml}$ at 72 weeks, and HBV DNA levels in one case rose from below the limit of detection at 84 weeks to $839 \mathrm{U} / 1$ at 96 weeks. The proportion of patients exhibiting undetectable HBV DNA levels at 144 weeks of treatment was higher among patients with HBeAg-negative status at baseline than among those with HBeAg-positive status (Fig. 2). Cox regression analysis demonstrated that the baseline HBV DNA level was a significant predictor of VR $(\mathrm{P}=0.012$; Table II). The VR rate was also compared between patients with baseline HBV DNA levels of $\geq 8$ vs. $<8 \log _{10} \mathrm{IU} / \mathrm{ml}$ at different time-points. The characteristics of patients stratified by their baseline HBV DNA levels are presented in Table III. The 29 patients with HBV DNA levels of $\geq 8 \log _{10} \mathrm{IU} / \mathrm{ml}$ at baseline achieved VR during the follow-up period. However, the cumulative VR rate was higher in patients with baseline HBV DNA levels of $<8 \log _{10} \mathrm{IU} / \mathrm{ml}$ than in those with baseline HBV DNA levels of $\geq 8 \log _{10} \mathrm{IU} / \mathrm{ml}$ ( $\mathrm{P}<0.01$; Fig. 3$)$. When patients were divided into groups with HBV DNA levels of $\geq 6$ and $<6 \log _{10} \mathrm{IU} / \mathrm{ml}$, the VR was revealed to be different between the two groups $(\mathrm{P}<0.05)$.

Factors predictive of PVR at 24 weeks. The baseline demographics and disease characteristics of those patients who exhibited a PVR at week 24 are summarized in Table IV. Cox regression analysis demonstrated that baseline HBV DNA levels and VR at 12 weeks were significant predictors of PVR $(\mathrm{P}=0.002$; Table V). A total of 35 cases $(26.9 \%)$ exhibited a PVR at 24 weeks. With continued therapy, 21 patients $(60 \%)$ with PVR at 24 weeks achieved VR at 48 weeks. At 96 weeks, 28 patients $(80 \%)$ had achieved VR. Another 2 patients achieved VR at 144 weeks, with HBV DNA remaining at a low level $\left(<3 \log _{10} \mathrm{IU} / \mathrm{ml}\right)$ prior to that. The remaining 5 patients did not achieve VR at the end of the study as the samples were detected only every three months, however, they were still included in the follow-up study. 
Table I. Characteristics of patients at baseline.

\begin{tabular}{lcccr}
\hline Parameter & Total $(\mathrm{n}=144)$ & HBeAg-positive $(\mathrm{n}=106)$ & HBeAg-negative $(\mathrm{n}=38)$ & P-value \\
\hline Male gender $(\%)$ & $80(55.6)$ & $52(49.1)$ & $28(73.7)$ & 0.032 \\
Age (years) & $34 \pm 7$ & $33 \pm 6$ & $38 \pm 9$ & 0.005 \\
Follow-up (weeks) & $120(12-264)$ & $144(12-264)$ & $90(12-240)$ & 0.363 \\
Presence of cirrhosis (\%) & $25(17.4)$ & $7(6.6)$ & $18(47.4)$ & $<0.001$ \\
Interferon experience & $5(3.5)$ & $3(2.8)$ & $2(5.3)$ & 0.781 \\
ALT (U/l) & $172.5 \pm 276.6$ & $169.0 \pm 175.2$ & $182.5 \pm 456.5$ & 0.967 \\
HBV DNA $\left(\log _{10} \mathrm{IU} / \mathrm{ml}\right)$ & $6.7 \pm 1.5$ & $7.1 \pm 1.3$ & $5.6 \pm 1.5$ & $<0.001$
\end{tabular}

Values are expressed as the mean \pm standard deviation, $\mathrm{n}(\%)$ or median (range). ALT, alanine aminotransferase (normal range, 5-40 U/l); HBV DNA, hepatitis B virus DNA (normal range, $<100 \mathrm{IU} / \mathrm{ml}$ ); $\mathrm{HBeAg}$, hepatitis B e antigen.

Biochemical response. The proportions of patients who exhibited ALT normalization at 24, 48, 96, 144, 192 and 240 weeks were 72.1, 78.6, 91.2, 95, 96 and 100\%, respectively. These proportions were not significantly different between patients with $\mathrm{HBeAg}$-positive and $\mathrm{HBeAg}$-negative status at baseline ( $\mathrm{P}=0.595$; Fig. 2).

Serological response. The proportion of patients who were $\mathrm{HBeAg}$-positive at baseline and exhibited HBeAg loss at 24, 48, 96, 144, 192 and 240 weeks was 6.2, 8.6, 18.4, 26.5, 29.7 and $35.6 \%$, respectively (Fig. 2). Furthermore, 2 patients achieved $\mathrm{HBeAg}$ seroconversion at week 48 and 60, respectively. In addition, 1 patient exhibited HBsAg loss at 120 weeks and the HBsAg titer at baseline was $160.5 \mathrm{IU} / \mathrm{ml}$, lower than that of $\mathrm{HBeAg-positive} \mathrm{patients.}$

Safety. No severe adverse events were reported during the present study. Transient elevations in creatine kinase levels were detected in 42 patients. All of them exhibited no muscle pain during the follow-up period. Of note, those patients performed a great deal of physical exercise. After they reduced the amount of exercise, creatine kinase was restored to normal. Serum creatinine level and estimated creatinine clearance were evaluated. Estimated creatinine clearance was calculated using the Modification of Diet in Renal Disease formula (13). The creatinine levels in a subset of 141 patients with an available baseline creatinine level were analyzed. A slightly elevated creatinine level $(153 \mu \mathrm{mol} / \mathrm{l})$ at week 12 was observed in one patient, but this reverted to the normal range $(31.6-116 \mu \mathrm{mol} / \mathrm{l})$ at 36 weeks. This patient took part in long-distance running and physical exercise at the gymnasium prior to the examination. After the patient was instructed to stop exercising, the level of creatinine gradually returned to normal. The median estimated glomerular filtration rate (eGFR) at baseline and at 48, 96, 144, 192 and 240 weeks was $131.96,122.66,119.35,121.25,113.93$ and $117.43 \mathrm{ml} / \mathrm{min} / 1.73 \mathrm{~m}^{2}$, respectively (Table VI). The eGFR decreased slightly from baseline to 240 weeks, but did not reach $<90 \mathrm{ml} / \mathrm{min} / 1.73 \mathrm{~m}^{2}$. Serum calcium levels were normal in all patients throughout the study period. Serum phosphorus levels decreased slightly among 3 patients, but after another 12 weeks' follow-up with continuous TDF administration, they reverted to the normal range (0.74-1.52 $\mathrm{mmol} / \mathrm{l})$.

\section{Discussion}

TDF is an oral NA and a potent and selective inhibitor of HBV DNA polymerase/reverse transcriptase in vitro. The safety and efficacy of TDF in the treatment of chronic HBV infection have been confirmed in phase 3 clinical trials that enrolled patients with $\mathrm{HBeAg}$-positive and $\mathrm{HBeAg}$-negative $\mathrm{CHB}$, respectively $(3,10)$. In the present study, the cumulative VR rate in TDF-naïve patients gradually increased throughout the treatment for up to 5 years in real life. Within the cohort, $>95 \%$ of the patients had undetectable HBV DNA levels after 96 weeks, all patients had undetectable HBV DNA levels after 144 weeks, and another 13 patients who were followed up until 240 weeks achieved complete VR. This result further confirmed the potent effectiveness of TDF in inhibiting HBV in real life.

Long-term treatment of CHB with TDF monotherapy has been reported to maintain effective suppression of HBV DNA over 8 years, with no evidence of TDF resistance or accumulation of polymorphic or conserved site changes (8). Therefore, $\mathrm{TDF}$ is recommended as the first-line therapeutic agent for $\mathrm{CHB}$ in clinical practice guidelines. In a previous study, the cumulative rate of VR in TDF-naïve CHB patients with a high viral load (HBV DNA level $\geq 6 \log _{10} \mathrm{IU} / \mathrm{ml}$ ) at 24 months was 92.8 and $98.2 \%$ in $\mathrm{HBeAg}$-positive and $\mathrm{HBeAg}$-negative patients, respectively (14). In another study, $7-24 \%$ of patients receiving TDF monotherapy for 48 weeks were reported to exhibit PVR (15). A 3-year, prospective, real-world study in France demonstrated VR in $90 \%$ of the patients after 12 weeks, irrespective of $\mathrm{HBeAg}$ status, age or prior treatment history (16). Another real-world study from Australia reported sustained complete virological suppression (defined as plasma HBV DNA level $<20 \mathrm{IU} / \mathrm{ml})$ in $70 \%$ of subjects $(29 / 44)$ at 12 months, $87 \%(26 / 30)$ at 24 months and $100 \%(18 / 18)$ at 36 months (12). In the present study, the cumulative rate of complete VR (defined as plasma HBV DNA level <100 IU/ml) at 24, 48,96 and 144 weeks was determined as 71,91.3 98.1 and $100 \%$. This result appears to be superior to the VR obtained in the Australian study (12). This may be due to the high lower detection limit of the HBV DNA undetectable status applied in the present study. The results of the current study, obtained in the clinical practice setting, are similar to results previously reported in clinical trials. 
A

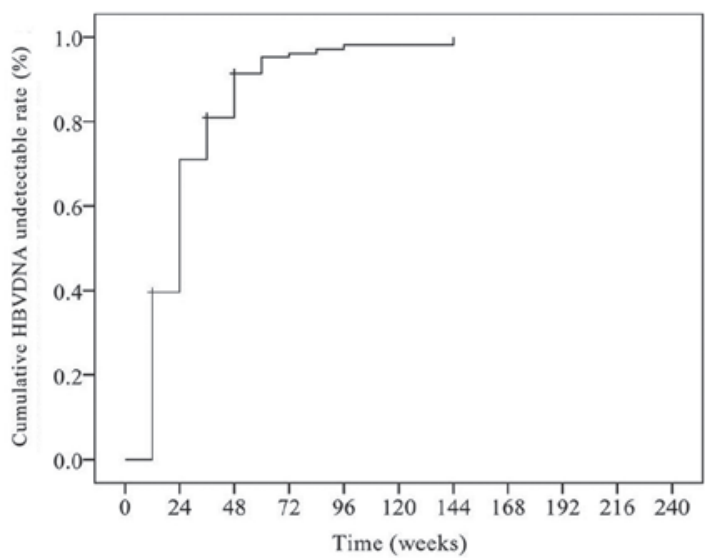

NO. remaining cases

$\begin{array}{lllllllllll}144 & 35 & 10 & 4 & 2 & 2 & 0 & 0 & 0 & 0 & 0\end{array}$

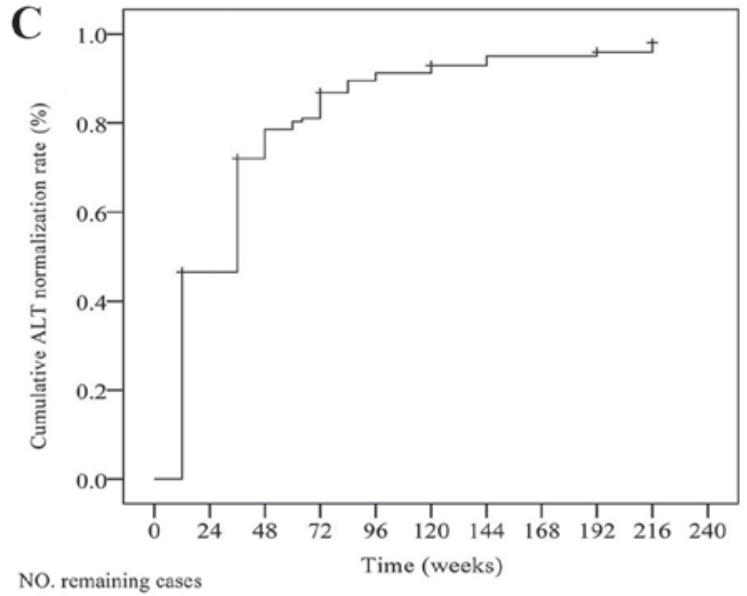

$\begin{array}{llllllllll}144 & 77 & 26 & 16 & 10 & 8 & 5 & 5 & 4 & 1\end{array}$

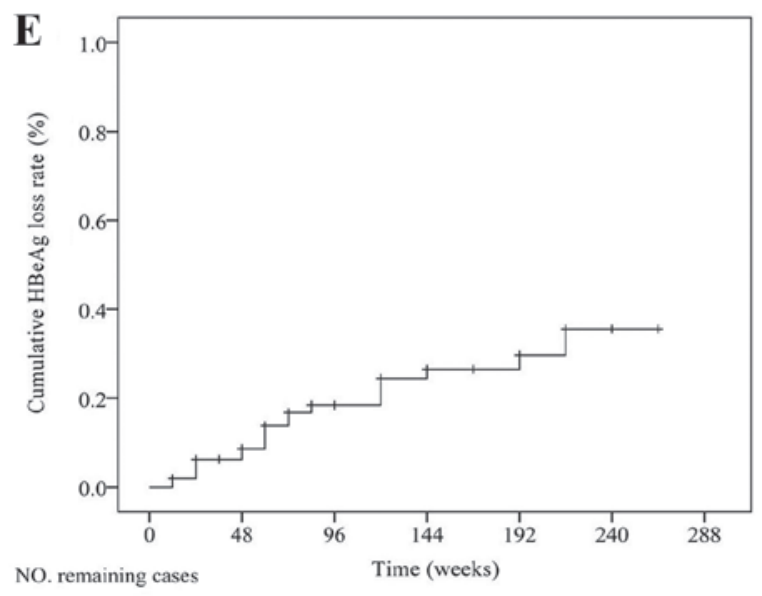

B

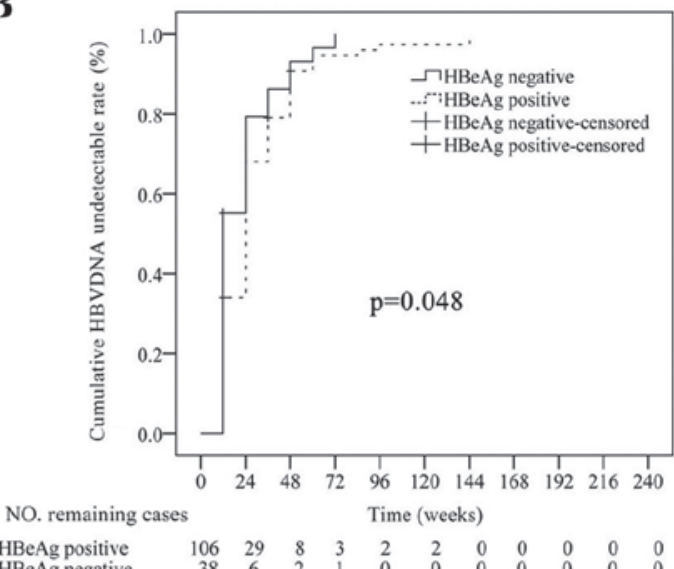

HBeAg positive

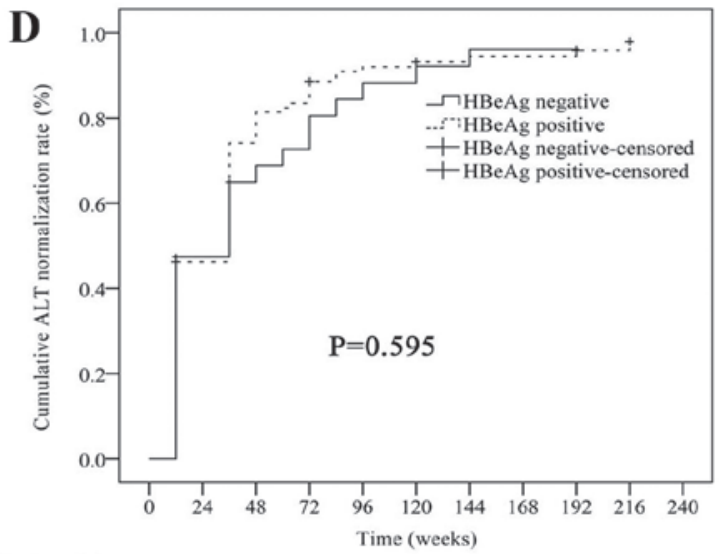

NO. remaining cases

$\begin{array}{lrrrrrrrrr}\text { HBeAg positive } & 106 & 57 & 18 & 11 & 7 & 6 & 4 & 4 & 3 \\ \text { HBeAg negative } & 38 & 20 & 8 & 5 & 3 & 2 & 1 & 1 & 1\end{array}$

Figure 2. Efficacy of tenofovir disoproxil fumarate treatment in CHB patients. (A) Cumulative HBV DNA undetectable rate and (B) comparison of cumulative HBV DNA undetectable rate compared between HBeAg-positive and -negative patients $(\mathrm{P}<0.05)$. (C) Cumulative ALT normalization rate and (D) comparison of cumulative ALT normalization rate compared between $\mathrm{HBeAg}$-positive and -negative patients ( $\mathrm{P}>0.05)$. (E) Cumulative $\mathrm{HBe} \mathrm{Ag}$ loss rate in $\mathrm{HBe} \mathrm{Ag}$-positive CHB patients at baseline. HBeAg, hepatitis B e antigen; ALT, alanine aminotransferase.

In the present study, a transient elevation of the viral load was observed in 6 patients, comprising an elevation of the HBV DNA level by $<1 \log$. However, in the subsequent second test, the HBV DNA level dropped below the detection limit. These patients had good medication adherence, and the transient elevation of viral load did not manifest as antiviral drug resistance. Hongthanakorn et al (17) also observed this virological breakthrough (VBT) phenomenon, which is defined as a $>1 \log _{10} \mathrm{IU} / \mathrm{ml}$ increase in serum HBV DNA levels from the nadir in two consecutive measurements (18), VBT is common in patients with chronic hepatitis B receiving nucleos(t)ide analogue treatment, but not all VBTs are due to drug resistance. The accountability of other reasons except for medication adherence is worth further exploration. 
Table II. Cox regression analysis for identification of independent variables predictive of virological response.

\begin{tabular}{lcccc}
\hline & \multicolumn{2}{c}{ Univariate analysis } & & Multivariate analysis \\
\cline { 2 - 3 } Variables & Hazard ratio $(95 \% \mathrm{CI})$ & P-value & Hazard ratio (95\% CI) & P-value \\
\hline Sex (males vs. females) & $0.915(0.644-1.301)$ & 0.621 & \\
Age (years) & $1.011(0.987-1.036)$ & 0.378 & \\
Presence of cirrhosis & $1.099(0.686-1758)$ & 0.695 & \\
History of interferon treatment prior to TDF & $1.692(0.687-4.166)$ & 0.252 & \\
HBeAg state at baseline (positive vs. negative) & $0.739(0.497-1.099)$ & 0.135 & \\
ALT (U/l) & $1.000(1.000-1.001)$ & 0.103 & $0.808(0.685-0.954)$ \\
HBV DNA at baseline $\left(\log _{10} \mathrm{IU} / \mathrm{ml}\right)$ & $0.866(0.770-0.974)$ & 0.016 & 0.012
\end{tabular}

ALT, alanine aminotransferase; HBV DNA, hepatitis B virus DNA; HBeAg, hepatitis B e antigen.

Table III. Characteristics of patients at baseline stratified by HBV DNA level.

\begin{tabular}{lccr}
\hline Parameter & HBV DNA $\geq 8 \log _{10} I U / m l(n=29)$ & HBV DNA $<8 \log _{10} I U / m l(n=115)$ & P-value \\
\hline Male gender $(\%)$ & $20(69)$ & $60(52.2)$ & 0.104 \\
Age (years) & $32 \pm 6$ & $35 \pm 7$ & 0.502 \\
Presence of cirrhosis (\%) & $1(3.4)$ & $24(20.9)$ & 0.027 \\
Interferon experienced & $0(0.0)$ & $5(4.3)$ & 0.583 \\
HBeAg-positive (\%) & $29(100)$ & $77(67)$ & $<0.001$ \\
ALT (U/l) & $156.6 \pm 172.0$ & $176.6 \pm 278.8$ & 0.722 \\
HBV DNA at baseline & $8.3 \pm 0.2$ & $6.3 \pm 1.3$ & $<0.001$
\end{tabular}

$\left(\log _{10} \mathrm{IU} / \mathrm{ml}\right)$

Values are expressed as the mean \pm standard deviation or $\mathrm{n}(\%)$. ALT, alanine aminotransferase; HBV DNA, hepatitis B virus DNA; HBeAg, hepatitis B e antigen.
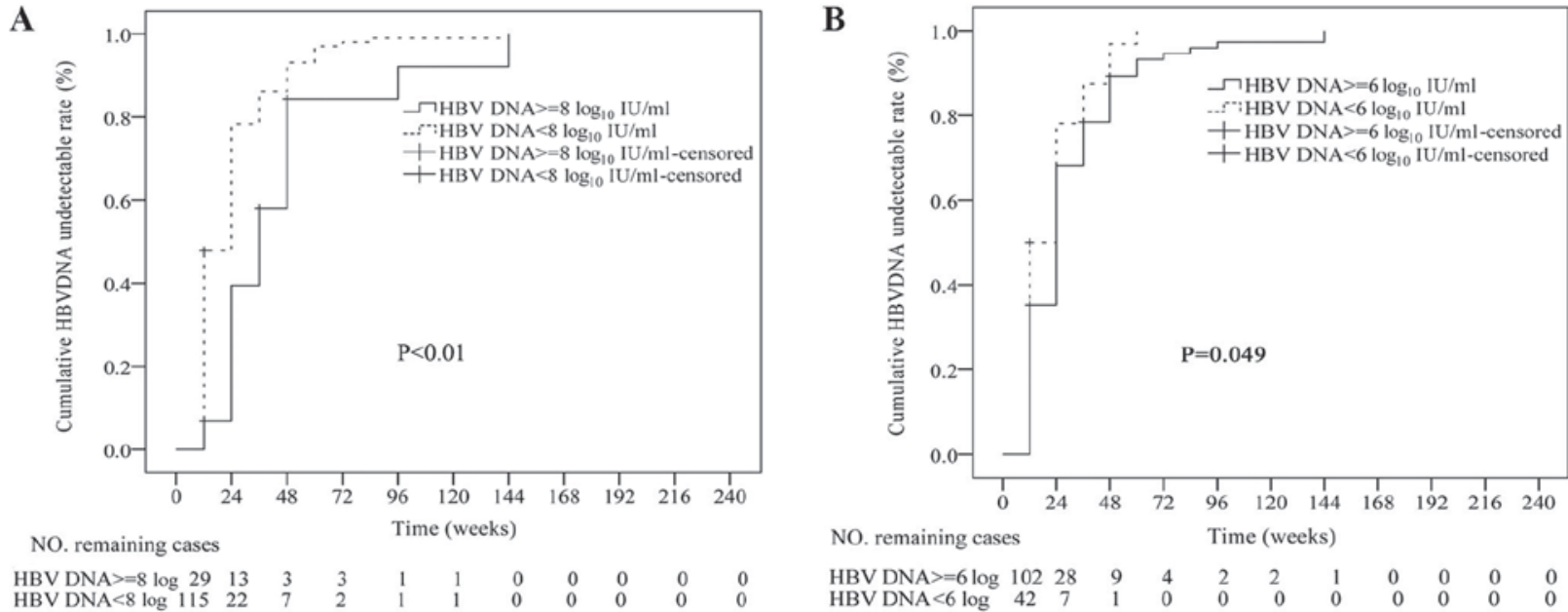

Figure 3. Cumulative HBV DNA undetectable rate in TDF-treated CHB patients with different baseline HBV DNA levels. (A) The cumulative HBV DNA undetectable rate was higher than in TDF-treated CHB patients with baseline HBV DNA $<8 \log _{10} \mathrm{IU} / \mathrm{ml}$ than in those with baseline HBV DNA $\geq 8 \log 10$ IU/ml $(\mathrm{P}<0.01)$. (B) The cumulative HBV DNA undetectable rate was higher in TDF-treated CHB patients with baseline HBV DNA $<6 \log _{10}$ IU $/ \mathrm{ml}$ than in those with baseline HBV DNA $\geq 6 \log _{10} \mathrm{IU} / \mathrm{ml}(\mathrm{P}=0.049)$. TDF, tenofovir disoproxil fumarate; CHB, chronic hepatitis $\mathrm{B}$; HBV, hepatitis B virus.

In the present study, a Cox regression analysis indicated that a high HBV DNA level at baseline was an independent factor influencing VR $(\mathrm{P}<0.05)$. When the patients were divided into two groups according to the baseline HBV DNA level ( $\geq 8$ and $\left.<8 \log _{10} \mathrm{IU} / \mathrm{ml}\right)$, the rate of VR was significantly different between the two groups $(\mathrm{P}<0.05)$. However, with continued 
Table IV. Baseline demographics of patients who exhibited a VR or PVR at 24 weeks.

\begin{tabular}{|c|c|c|c|c|}
\hline Parameter & Total $(n=130)$ & VR (n=95) & $\operatorname{PVR}(\mathrm{n}=35)$ & P-value \\
\hline Male gender $(\%)$ & $72(55.4)$ & $53(55.8)$ & $19(54.3)$ & 0.878 \\
\hline Age (years) & $34.1 \pm 6.7$ & $34.1 \pm 6.8$ & $34.0 \pm 6.6$ & 0.771 \\
\hline Presence of cirrhosis $(\%)$ & $20(15.4)$ & $14(14.7)$ & $6(17.1)$ & 0.736 \\
\hline Interferon experienced & $4(3.1)$ & $4(4.2)$ & $0(0.0)$ & 0.218 \\
\hline HBeAg-positive & $98(75.4)$ & $68(71.6)$ & $30(85.7)$ & 0.097 \\
\hline $\operatorname{ALT}(\mathrm{U} / \mathrm{l})$ & $175.9 \pm 287.6$ & $202.7 \pm 325.5$ & $103.4 \pm 116.5$ & 0.052 \\
\hline HBV DNA at baseline $\left(\log _{10} \mathrm{IU} / \mathrm{ml}\right)$ & $6.7 \pm 1.4$ & $6.5 \pm 1.4$ & $7.3 \pm 1.4$ & 0.652 \\
\hline
\end{tabular}

Values are expressed as the mean \pm standard deviation or $\mathrm{n}(\%)$. ALT, alanine aminotransferase; HBV DNA, hepatitis B virus DNA; HBeAg, hepatitis B e antigen; PVR, partial virological response.

Table V. Cox analyses of host and viral factors associated with undetectable levels of HBV DNA at 24 weeks.

\begin{tabular}{|c|c|c|c|c|}
\hline \multirow[b]{2}{*}{ Variables } & \multicolumn{2}{|c|}{ Univariate analysis } & \multicolumn{2}{|c|}{ Multivariate analysis } \\
\hline & Hazard ratio $(95 \% \mathrm{CI})$ & P-value & Hazard ratio $(95 \% \mathrm{CI})$ & P-value \\
\hline Sex (males vs. females) & $0.936(0.624-1.404)$ & 0.750 & & \\
\hline Age (years) & $1.002(0.974-1.031)$ & 0.888 & & \\
\hline Presence of cirrhosis & $0.913(0.518-1.610)$ & 0.754 & & \\
\hline Interferon experienced & $0.715(0.457-1.118)$ & 0.404 & & \\
\hline HBeAg status at baseline (positive vs. negative) & $1.532(0.562-4.172)$ & 0.141 & & \\
\hline $\operatorname{ALT}(\mathrm{U} / \mathrm{l})$ & $1.000(1.000-1.001)$ & 0.112 & & \\
\hline HBV DNA at baseline (log $10 \mathrm{IU} / \mathrm{ml})$ & $0.853(0.747-0.975)$ & 0.020 & $0.760(0.641-0.901)$ & 0.002 \\
\hline
\end{tabular}

ALT, alanine aminotransferase; HBV DNA, hepatitis B virus DNA; HBeAg, hepatitis B e antigen

Table VI. Change in eGFR in tenofovir treatment-naïve chronic hepatitis $\mathrm{B}$ patients.

\begin{tabular}{ll}
\hline Time (weeks) & eGFR $\left(\mathrm{ml} / \mathrm{min} / 1.73 \mathrm{~m}^{2}\right)$ \\
\hline Baseline & $131.96(58.51-292.75)$ \\
48 & $122.66(73.49-200.86)$ \\
96 & $119.35(80.79-203.08)$ \\
144 & $121.25(79.43-193.43)$ \\
192 & $113.93(80.9-196.32)$ \\
240 & $117.43(88.41-214.3)$ \\
\hline
\end{tabular}

Values are expressed as the median (range). eGFR, estimated glomerular filtration rate (normal range, $>90 \mathrm{ml} / \mathrm{min} / 1.73 \mathrm{~m}^{2}$ ).

treatment, the VR rate in each group had reached $100 \%$ after 144 weeks. At present, there is no clear definition of high viral load, and certain studies regard HBV DNA levels of $\geq 6$ $\log _{10} \mathrm{IU} / \mathrm{ml}$ as indicative of high viral load (11). Therefore, in the present study, HBV DNA levels of $\geq 6$ and $\geq 8 \log _{10} \mathrm{IU} / \mathrm{ml}$ were considered for assessment. The patients were divided into two groups based on baseline HBV DNA levels of $\geq 6$ or $<6 \log _{10}$ IU/ $\mathrm{ml}$ and it was observed that the VR was different between the two groups $(\mathrm{P}<0.05)$. This result provides further evidence that TDF is highly effective for CHB patients with a high viral load. A previous study by our group has demonstrated that TDF and ETV rapidly inhibit HBV DNA replication in $\mathrm{HBeAg}$-positive CHB patients with high HBV DNA levels (19). However, another study demonstrated that TDF is superior to ETV in achieving complete viral suppression in HBeAg-positive CHB patients with high HBV DNA levels (HBV DNA level $>6 \log _{10} \mathrm{IU} / \mathrm{ml}$ ), with no significant difference in viral suppression in HBeAg-negative patients (11). These results provide a reference for the selection of anti-viral drugs in patients with chronic HBV with a high viral load.

Previous studies reported that high baseline HBV DNA and HBeAg positivity are independent risk factors for PVR $(20,21)$. In the present study, the e-antigen state at baseline appeared to have no effect on the VR at 24 weeks in TDF-treated patients, as indicated by Cox univariate and multivariate logistic regression analysis. There may be several reasons for this observation. First, the overall sample size of the present study was relatively small, and the proportion of $\mathrm{HBeAg-negative}$ patients in the overall population was $<27 \%$. Furthermore, the mean value of HBV DNA at baseline was similar to that of HBeAg-negative and HBeAg-positive patients.

The presence of PVR, particularly to treatment with lamivudine, telbivudine and adefovir, is linked to the high 
risk of resistance to long-term anti-HBV treatment in these patients (22). Conversely, for drugs with a high resistance barrier, including ETV and TDF, PVR is associated with a lower risk of resistance to long-term monotherapy. A previous study by our group suggests that adjustment of ETV monotherapy may not be required in NA-naïve patients with a PVR at 1 year if no resistance to ETV has occurred by then; most patients achieved VR if therapy was continued beyond 1 year (23).

In the present study, 35 cases $(26.9 \%)$ achieved a PVR at 24 weeks. With continued therapy, 21 patients (60\%) with a PVR at 24 weeks achieved VR at 48 weeks. After 3 years, $>80 \%$ of the patients had achieved VR. No virological breakthroughs were observed during this process. A Korean study reported that 127 out of 177 patients with PVR $(71.8 \%)$ achieved VR during continuous prolonged TDF therapy (20). It also suggested that the vast majority of $\mathrm{CHB}$ patients with PVR achieved VR through prolonged TDF therapy, and it was unnecessary to urgently implement salvage therapy for TDF-naïve CHB patients with PVR.

In addition to undetectable HBV DNA levels, the disappearance of $\mathrm{HBsAg}$ and even the emergence of $\mathrm{HBs} \mathrm{Ab}$ are ideal treatment goals for $\mathrm{CHB}$ patients. In the present study, only one patient exhibited loss of HBsAg, and no serum conversion occurred. Among the $\mathrm{HBeAg}$-positive patients at baseline, 20 patients achieved HBeAg loss until 192 weeks. Of those 20 patients, 2 achieved $\mathrm{HBeAg}$ seroconversion at weeks 48 and 60. The proportion of patients exhibiting HBeAg loss in the present study was lower than that reported previously (35.6 vs. $45.0 \%$ ) by Marcellin et al (16). Novel drugs and strategies should be developed to achieve the goal of HBsAg seroconversion after VR, which remains a challenge.

No severe adverse events were reported in the present study. The serum phosphorus levels decreased slightly in 3 patients and were restored to the normal range without discontinuation of the treatment. The eGFR decreased slightly from baseline to 144 weeks, but always remained $>90 \mathrm{ml} / \mathrm{min} / 1.73 \mathrm{~m}^{2}$. Until 144 weeks, the eGFR subsequently stabilized gradually. Tsai et al (24) reported that the eGFR decreased significantly in the TDF group after a mean of 17 months of treatment, while Wang et al (25) observed that the eGFR decreased in patients with TDF treatment within 12 weeks. López Centeno et al (26) indicated no significant differences in terms of renal safety between CHB patients treated with ETV and TDF. Another study reported no significant differences in the eGFR in either the ETV- or TDF-treated patients with compensated cirrhosis or decompensated cirrhosis at week 96 (27). However, adverse events, including Fanconi syndrome, asthenia, hypophosphatemia and abdominal pain, have been reported to be associated with TDF (12). Therefore, regular follow-up examination is important and treatment decisions should be based on individualized assessments of each patient.

A relevant limitation of the present study is the small sample size. It is regrettable that resistance was not evaluated in patients with PVR at 24 weeks. In the majority of patients, quantitative analysis of HBsAg was not detected.

In conclusion, long-term treatment with TDF for up to 5 years significantly reduced HBV DNA levels in $\mathrm{CHB}$ patients, regardless of high viral load at baseline. Adjustment of TDF monotherapy in NA-naïve patients with PVR at
24 weeks may not be required, and most patients achieved VR if therapy was continued.

\section{Acknowledgements}

Not applicable.

\section{Funding}

This project was supported by the Natural Science Foundation of Guangdong (grant nos. 2014A030313146, 2016A030313250 and 2016A030313302), the Tianhe District Science and Technology Project (grant no. 201504KW032) and the Jiangxi Science and Technology Project (grant no. 20151BBG70163).

\section{Availability of data and materials}

The datasets used and/or analyzed during the present study are available from the corresponding author on reasonable request.

\section{Authors' contributions}

JL, XYL and XY wrote the manuscript. YC, JL, XYL and ZL designed the study. JL, XY, ZL, XYL, YW, JG, YJ, XHL, SX, ZZ, YZ and DX collected the patient data. JL, XY, ZL and XYL analyzed the data and revised the manuscript. All authors read and approved the final manuscript.

\section{Ethical approval and consent to participate}

The present study was approved by the Ethics Committee of the Third Affiliated Hospital of Sun Yat-sen University (Guangdong, China). Written informed consent was obtained from all patients.

\section{Patient consent for publication}

Not applicable.

\section{Competing interests}

The authors declare that they have no competing interests.

\section{References}

1. Wang FS, Fan JG, Zhang Z, Gao B and Wang HY: The global burden of liver disease: The major impact of China. Hepatology 60: 2099-2108, 2014.

2. Chinese Society of Hepatology and Chinese Society of Infectious Diseases, Chinese Medical Association: The Guideline of Prevention and Treatment for Chronic Hepatitis B (2015 Version). J Clin Hepatol 31: 1941-1960, 2015.

3. Marcellin P, Heathcote EJ, Buti M, Gane E, de Man RA, Krastev Z, Gemanidis G, Lee SS, Flisiak R, Kaita K, et al: Tenofovir disoproxil fumarate versus adefovir dipivoxil for chronic hepatitis B. N Engl J Med 359: 2442-2455, 2008.

4. Buti M, Tsai N, Petersen J, Flisiak R, Gurel S, Krastev Z, Aguilar Schall R, Flaherty JF, Martins EB, Charuworn P, et al: Seven-year Efficacy and safety of treatment with tenofovir disoproxil fumarate for chronic hepatitis B virus infection. Dig Dis Sci 60: 1457-1464, 2015.

5. Sarin SK, Kumar M, Lau GK, Abbas Z, Chan HL, Chen CJ, Chen DS, Chen HL, Chen PJ, Chien RN, et al: Asian-Pacifc clinical practice guide-lines on the management of hepatitis B: A 2015 update. Hepatol Int 10: 1-98, 2016. 
6. Terrault NA, Bzowej NH, Chang KM, Hwang JP, Jonas MM, Murad MH, American Association for the Study of Liver Diseases, et al: AASLD guidelines for treatment of chronic hepatitis B. Hepatology 63: 261-283, 2016.

7. Lampertco P, Maini M and Papatheodoridis G: Optimal management of hepatitis B virus infection-EASL special conference. J Hepatol 63: 1238-1253, 2015.

8. Liu Y, Corsa AC, But M, Cathcart AL, Flaherty JF, Miller MD, Kitrinos KM, Marcelin P and Gane EJ: No detectable resistance to tenofovir disoproxil fumarate in $\mathrm{HBeAg}+$ and $\mathrm{HBeAg}$-patents with chronic hepatts B afer 8 years of treatment. J Viral Hepat 24 68-74, 2016.

9. Lim YS, Lee YS, Gwak GY, Byun KS, Kim YJ, Choi J, An J, Lee HC, Yoo BC and Kwon SY: Monotherapy with tenofovir disoproxil fumarate for multiple drug-resistant chronic hepatitis B: 3-year trial. Hepatology 66: 772-783, 2017.

10. Gordon SC, Krastev Z, Horban A, Petersen J, Sperl J, Dinh P, Martins EB, Yee LJ, Flaherty JF, Kitrinos KM, et al: Efficacy of tenofovir disoproxil fumarate at 240 weeks in patients with chronic hepatitis B with high baseline viral load. Hepatology 58 : 505-513, 2013

11. Gao L, Trinh HN, Li J and Nguyen MH: Tenofovir is superior to entecavir for achieving complete viral suppression in HBeAg-positive chronic hepatitis B patients with high HBV DNA. Aliment Pharmacol Ther 39: 629-637, 2014.

12. Lovett GC, Nguyen T, Iser DM, Holmes JA, Chen R, Demediuk B, Shaw G, Bell SJ, Desmond PV and Thompson AJ: Efficacy and safety of tenofovir in chronic hepatitis B: Australian real world experience. World J Hepatol 9: 48-56, 2017.

13. Ma YC, Zuo L, Chen JH, Luo Q, Yu XQ, Li Y, Xu JS, Huang SM, Wang LN, Huang W, et al: Modified glomerular filtration rate estimating equation for Chinese patients with chronic kidney disease. J Am Soc Nephrol 17: 2937-2944, 2006

14. Wu IT, Hu TH, Hung CH, Lu SN, Wang JH, Lee CM and Chen $\mathrm{CH}$ : Comparison of the efficacy and safety of entecavir and tenofovir in nucleos(t)ide analogue-naive chronic hepatitis $B$ patients with high viraemia: A retrospective cohort study. Clin Microbiol Infect 23: 464-469, 2017.

15. Lampertico P: Partial virological response to nucleos(t)ide analogues in naïve patients with chronic hepatitis B: From guidelines to field practice. J Hepatol 50: 644-647, 2009.

16. Marcellin P, Zoulim F, Hezode C, Causse X, Roche B, Truchi R, Pauwel A, Ouzan D, Dumortier J, Pageaux GP, et al: Effectiveness and safety of tenofovir disoproxil fumarate in chronic Hepatitis B: A 3-year, prospective, real-world study in France. Dig Dis Sci 61: 3072-3083, 2016.

17. Hongthanakorn C, Chotiyaputta W, Oberhelman K, Fontana RJ, Marrero JA, Licari T and Lok AS: Virological breakthrough and resistance in patients with chronic hepatitis $\mathrm{B}$ receiving nucleos(t)ide analogues in clinical practice. Hepatology 53: $1854-1863,2011$
18. European Association For The Study Of The Liver. Electronic address: easloffice@easloffice.eu; European Association for the Study of the Liver: EASL 2017 Clinical Practice Guidelines on the management of hepatitis B virus infection. J Hepatol 67: 370-398, 2017.

19. Shi H, Huang M, Lin GL, Li X, Wu Y, Jie Y and Chong Y: Efficacy comparison of tenofovir and entecavir in $\mathrm{HBeAg}$-positive chronic hepatitis B patients with high HBV DNA. Biomed Res Int 2016: 6725073,2016

20. Du Jeong I, Jung SW, Park BR, Lee Bu, Park JH, Kim BG, Bang SJ, Shin JW and Park NH: Clinical course of partial virologic response with prolonged Tenofovir therapy in Nuclos(t)ides-naive patients with chronic hepatitis B. Dig Dis Sci 62: 2908-2914, 2017

21. Zoutendijk R, Reijnders JG, Brown A, Zoulim F, Mutimer D, Deterding K, Petersen J, Hofmann WP, Buti M, Santantonio T, et al: Entecavir treatment for chronic hepatitis B: Adaptation is not needed for the majority of naive patients with a partial virological response. Hepatology 54: 443-451, 2011.

22. European Association for the Study of the Liver: EASL clinical practice guide-lines: Management of chronic hepatitis B. J Hepatol 50: 227-242, 2009.

23. Luo J, Li X, Wu Y, Lin G, Pang Y, Zhang X, Ao Y, Du Z, Zhao Z and Chong Y: Efficacy of entecavir treatment for up to 5 years in Nucleos(t)ide-naïve chronic hepatitis B patients in real life. Int J Med Sci 10: 427-433, 2013

24. Tsai MC, Chen CH, Tseng PL, Hung CH, Chiu KW, Wang JH, Lu SN, Lee CM, Chang KC, Yen YH, et al: Comparison of renal safety and efficacy of telbivudine, entecavir and tenofovir treatment in chronic hepatitis B patients: Real world experience. Clin Microbiol Infect 22: 95.e1-e7, 2016.

25. Wang HM, Hung CH, Lee CM, Lu SN, Wang JH, Yen YH, Kee KM, Chang KC, Tseeng PL, Hu TH and Chen CH: Three-year efficacy and safety of tenofovir in nucleos(t)ide analog-naïve and nucleos $(\mathrm{t})$ ide analog-experienced chronic hepatitis B patients. J Gastroenterol Hepatol 31: 1307-1314, 2016.

26. López Centeno B, Collado Borrell R, Pérez Encinas M, Gutierrez Garcia ML and Sanmartin Fenollera P: Comparison of the effectiveness and renal safety of tenofovir versus entecavir in patients with chronic hepatitis B. Farm Hosp 40: 279-286, 2016.

27. Park J, Jung KS, Lee HW, Kim BK, Kim SU, Kim DY, Ahn SH, Han KH and Park JY: Effects of entecavir and tenofovir on renal function in patients with hepatitis B virus-related compensated and decompensated cirrhosis. Gut Liver 11: 828-834, 2017. 